American University Washington College of Law

Digital Commons @ American University Washington College of

Law

Articles in Law Reviews \& Other Academic Journals

Scholarship \& Research

2006

Religious Liberty and the Law

Stephen Wermiel

Follow this and additional works at: https://digitalcommons.wcl.american.edu/facsch_lawrev

Part of the Education Law Commons, First Amendment Commons, Law and Society Commons, Religion Law Commons, and the State and Local Government Law Commons 


\section{Religious Liberty and the Law}

\section{By Stephen J. Wermiel}

$\mathbf{A}$ 1though it has been 215 years since the Establishment and Free Exercise Clauses were added by amendment to the Constitution, there are few facets of American life that more deeply divide the nation today than the meaning of religious freedom.

The questions are by now quite familiar. Does free exercise mean neutrality or accommodation? Does establishment mean the Thomas Jefferson-generated metaphor of "a wall of separation" between church and state or is that the wrong image? Does establishment mean an absence of government endorsement or coercion? Or does establishment mean the ability of government to favor religion over nonreligion, to recognize the role of religion in American society?

In his last opinion, making reference to the two-faced ancient Roman god Janus, the late Chief Justice William Rehnquist described the tension over the Establishment Clause, not only within the Court but in society in general. "Our cases, Januslike, point in two directions in applying the Establishment Clause. One face looks toward the strong role played by religion and religious traditions throughout our Nation's history. ... The other face looks toward the principle that governmental intervention in religious matters can itself endanger religious freedom," Rehnquist wrote. Van Orden $v$. Perry, 125 S. Ct. 2854, 2859 (2005).

The answers do not seem to get any easier or less divisive, in the United States or in countries throughout the world. This issue of Human Rights is designed to explore some of the controversy and tension over the meaning of religious freedom in different settings.

Some current controversies are examined in very specific detail, for example, the story of Georgia's new law creating an elective class in Bible study in the state's public schools. The Georgia law, using the Bible as a textbook, squarely presents the conflict between teaching about religion and advancing religious beliefs. Implementation of the Georgia law will be watched closely by other state legislatures and could provoke a range of lawsuits. We have also staged our own mini-debate over President George W. Bush's Faith-Based Initiative, presenting sidebars that are for and against the inclusion of religious organizations in the implementation of federal grants to provide various social services. And we have focused on the increasingly cited claims of conscience by pharmacists and other health professionals who object to providing emergency contraceptives on religious and moral grounds.

Feature articles in this issue explore religious freedom from a variety of important angles. There is an overview of the legal battlegrounds that continue to be where much of the skirmishing is fought over the proper role of religion in American society. Articles examining the tensions over religion in the schools, in the workplace, and in the political arena are also included.

Many other pressing matters are not covered in this issue. One is the continuing litigation over the phrase "under God" in the Pledge of Allegiance. The Supreme Court threw out one lawsuit for lack of standing, Elk Grove Unified School District $v$. Newdow, 542 U.S. 1 (2004), reversing an earlier ruling by the Ninth Circuit Court of Appeals against a California school district's use of the Pledge, Newdow v. U.S. Congress (Newdow III), 328 F.3d 466 (2003). But Newdow is back with a broader group of plaintiffs, and after a new win in federal district court, Newdow v. Congress, $383 \mathrm{~F}$. Supp. $2 \mathrm{~d} 1229$ (2005), the case is on appeal, Newdow v. Carey, 05-17257 (9th Cir. 2006), inviting a renewed examination of the Pledge by the Ninth Circuit that is almost certain to find its way back to the Supreme Court in a year or two. As it has for several years, the case raises the question of whether it violates the Establishment Clause for a school system to have teachers lead students in a patriotic recitation that pledges devotion not only to the nation but also to God.

We have made only passing reference to the fight in various parts of Europe over Muslims wearing veils, headscarves, or other religious items. The issue flares up regularly. House of Commons leader Jack Straw touched off a new, heated debate in Great Britain in October 2006 when he said he asks Muslim women to remove their veils if they visit his legislative office to seek his help. Similar controversies have occurred in Denmark, France, and elsewhere. The issue has tested the willingness of many countries to tolerate religious customs and traditions in different settings, including schools and the workplace.

The range of subjects discussed in this edition of Human Rights sheds light on how legal issues about religion affect our lives in different ways and on how the principles of the First Amendment serve changing times.

Stephen.J. Wermiel is associate director of the MarshallBrennan Constitutional Literacy Project, a program of law students teaching in Washington-area public schools through American University's Washington College of Law. He was the Wall Street Journal's Supreme Court correspondent from 1979 to 1991 . 